\title{
Supplemental Calcium Application Influences Potato Tuber Number and Size
}

\author{
Senay Ozgen ${ }^{1}$ and Jiwan P. Palta ${ }^{2}$ \\ Department of Horticulture, 1575 Linden Drive, University of Wisconsin, \\ Madison, WI 53706-1590
}

Additional index words. Solanum tuberosum, 'Russet Burbank', calcium nutrition, nitrogen nutrition, tuber calcium concentration, potato yield, potato quality, tuberization, tuber induction

\begin{abstract}
Tuberization in potato is known to be under complex biochemical control involving hormones. A number of studies have provided evidence for a critical role of GA in tuberization. There is also evidence that $\mathrm{GA}$ in plants can be modulated by a $\mathrm{Ca}$ /calmodulin pathway. The purpose of the present study was to determine the influence of supplemental Ca fertilization on tuber size and tuber number. Plantlets of Solanum tuberosum 'Russet Burbank' raised in tissue culture were planted in 20 -L pots filled with sandy loam field soil with the $\mathrm{pH}$ of 6.9 and exchangeable soil Ca level of $350 \mathrm{ppm}$. All treatments received the same total amount of $\mathrm{N}$ (equivalent to the rate of $280 \mathrm{~kg}^{-h^{-1}}$ ). Four treatments were evaluated: nonsplit $\mathbf{N}$ (from ammonium nitrate), split $\mathbf{N}$ (from ammonium nitrate), split $\mathbf{N}+\mathrm{Ca}$ (from calcium nitrate), split $\mathrm{N}+\mathrm{Ca}(50 \% \mathrm{~N}$ from urea, $50 \% \mathrm{~N}$ from ammonium nitrate and Ca from calcium chloride). The total Ca was applied at the rate equivalent to $168 \mathrm{~kg} \cdot \mathrm{ha}^{-1}$ on a split schedule (equally split at four, six, eight and ten weeks after planting). Four months after planting tubers were harvested and evaluated. As expected tuber tissue Ca was increased by Ca application from 144 to $245 \mu \mathrm{g} \cdot \mathrm{g}^{-1}$. In general, the two Ca treatments had significantly lower tuber number per plant as compared to the nonsplit and split $\mathrm{N}$ treatments. A plot of mean tuber $\mathrm{Ca}$ and tuber number for individual plants showed a significant negative relationship. Both Ca treatments produced tubers with higher mean tuber weight compared to nonsplit $\mathrm{N}$. This increase in tuber size with $\mathrm{Ca}$ application was not apparent when compared with split $\mathrm{N}$ treatment. These results show that $\mathrm{Ca}$ application to soil can decrease tuber number suggesting that soil Ca may influence tuberization in potato.
\end{abstract}

Tuberization in potato (Solanum tuberosum L.) plants is a complex process that is known to beinfluenced by photoperiod, temperatures, and $\mathrm{N}$ nutrition (Batutis and Ewing, 1982; Ewing and Struik, 1992; Ewing and Wareing, 1978; Koda and Okazawa, 1983; Li, 1985; Menzel, 1985; Jackson, 1999; Snyder and Ewing, 1989). For example short days (longer than a critical length of the night period) promote tuberization (Batutis and Ewing, 1982; Ewing and Wareing, 1978; Jackson, 1999) whereas high temperatures and $\mathrm{N}$ inhibits tuberization (Li, 1985; Menzel, 1983, 1985). Although the exact mechanism of how environmental and nutritional factors affect tuberization is not known, many studies have implicated the role of plant hormones in modulating tuberization in potato (see for review Ewing, 1995).

Among the known hormones, the most convincing case for a critical role in the control of tuberization, has been made for gibberellin (Ewing, 1995; Jackson, 1999; Koda and Okazawa, 1983). High GA level inhibited tuberization and tuberization was promoted by

Received for publication 11 Dec. 2003. Accepted for publication 3 Mar. 2004. This research was supported by the College of Agriculture and Life Sciences, Univ. of Wisconsin-Madison, and by a grant from the Wisconsin State Potato Industry Board.

${ }^{1}$ Graduate research assistant.

${ }^{2}$ Campbell-Bascom professor of horticulture. To whom reprint request should be addressed; e-mail jppalta@wisc.edu. reducing GA level. For example, Jackson and Prat (1996) were able to induce tuberization in long days (otherwise noninducing conditions) by inhibiting GA biosynthesis with ancymidol. Inhibition of tuberization by high temperatures has been linked to enhanced GA level and reduction in inhibitors such as ABA (Menzel, 1980). In follow up studies Menzel $(1983,1985)$ found that high temperatures promoted GA synthesis in the buds which reduced tuberization. Similarly the inhibition of tuberization by high $\mathrm{N}$ was explained in terms of increased GA level (Krauss, 1985; Krauss and Marschner, 1982). A recent study by Xu et al. (1998) also demonstrated a decrease in GA during tuber initiation in vitro cultured single node cuttings. From these studies the authors concluded GA to be a dominant regulator of tuber initiation and growth.

There is some evidence indicating the involvement of $\mathrm{Ca}$ in tuberization (Balamani et al., 1986). Tuberization was inhibited in a single node leaf cutting by Ca chelator EGTA and $\mathrm{Ca}$ ionophore A 23187. Tuberization was restored by including $\mathrm{CaCl}_{2}$ in the medium. Poovaiah et al. (1996) developed a transgenic plant over expressing PCM1, a potato calmodulin isoform. These plants had reduced tuberization and exhibited a phenotype reminiscent of GA treated potato plants. Other studies on the changes in barley aleurone during germination contain evidence for the modulation of GA by $\mathrm{Ca} /$ calmodulin pathway (Bush et al., 1993; Gilroy and Jones, 1993). These studies have provided evidence for a powerful interaction between cytosolic $\mathrm{Ca}$ and GA action. Free cytosolic $\mathrm{Ca}$ has also been demonstrated to be a major metabolic regulator participating in the signal transduction (Hepler and Wayne, 1985; Marme, 1982; Poovaiah, 1985; Poovaiah and Reddy, 1987). In addition, the role of $\mathrm{Ca}$ in the maintenance of membrane integrity and cell wall strength is well established (Clarkson and Hanson, 1980; Marschner, 1995; Palta, 1996). There is also evidence for the presence of Ca-dependent and calmodulin-independent protein kinase which is thought to modulate plant growth and development (Roberts and Harmon, 1992). Thus, it is possible that $\mathrm{Ca}$ could regulate tuberization process in potato. In fact a recent review by Jackson (1999) suggested $\mathrm{Ca} /$ calmodulin to be a signaling pathway regulating potato tuberization. In the present study we report the influence of root zone $\mathrm{Ca}$ on tuberization.

\section{Materials and Methods}

Plants of 'Russet Burbank' were raised from micropropagated stem cuttings. For this purpose, single node cuttings were transferred to a sterile MS (Murashige and Skoog, 1962) culture media for $21 \mathrm{~d}$ under continuous light with about $60 \mu \mathrm{mol} \cdot \mathrm{m}^{-2} \cdot \mathrm{s}^{-1}$ photosynthetic photon flux (PPF) from cool white fluorescent lamps (Steffen and Palta, 1986). Uniform rooted and single stemmed micropropagated plantlets were transplanted to $5 \times 6 \mathrm{~cm}$ plant containers filled with Jiffy Mix (JPA, Chicago, Ill.). Transplants were kept covered with clear plastic for the first $2 \mathrm{~d}$ to minimize transplant shock and avoid desiccation. Two weeks after transplanting, plants were transferred to 20-L (30$\mathrm{cm}$-diameter) pots containing 1:1 (by volume) Plainfield loamy sand (sandy, mixed, mesic, Typic Udipsammet) and perlite. The soil for this purpose was collected from the top 15 to $20 \mathrm{~cm}$ layer at the University of Wisconsin-Madison Hancock Agricultural Research station. This soil is typical of that commercial production of potatoes in Wisconsin. Soil analyses gave values of $2 \mathrm{meq} / 100 \mathrm{~g}$ cation exchange capacity, $0.7 \%$ organic matter, and nutrients $\left(\mathrm{mg} \cdot \mathrm{kg}^{-1}\right.$ soil) 66 $(\mathrm{P}), 160(\mathrm{~K}), 350(\mathrm{Ca})$, and $100(\mathrm{Mg})$ (Standard soil analysis performed by University of Wisconsin Soil and Forage Laboratory). Based on a plant population of 35,960 plants/ha, the $\mathrm{N}$ $\mathrm{P} K$ requirement per plant were calculated on individual plant basis. This amounted to 7.81 $\mathrm{g}$ of $\mathrm{N}, 4.3 \mathrm{~g}$ of $\mathrm{P}$ and $4.3 \mathrm{~g}$ of $\mathrm{K}$ per plant. For each pot all of the $\mathrm{P}$ and $\mathrm{K}$ and some of N (1.09 g) was mixed with soil before planting.

The experiment was conducted in a greenhouse at the University of Wisconsin-Madison. A randomized complete block design with four nutrient treatments and eight replications per treatment was used. Each replication for every nutrient treatment consisted of one plant. Daily minimum and maximum temperatures were about $20 / 18^{\circ} \mathrm{C}$ during the experimental period. The photoperiod was $14 \mathrm{~h}$ with photosynthetically active radiation of 400 to $600 \mu \mathrm{mol} \cdot \mathrm{m}^{-2} \cdot \mathrm{s}^{-1}$ at the top of the plant canopy from alternating high pressure sodium and metal halide lamps.

Two weeks after planting in the $20-\mathrm{L}$ pots $3.12 \mathrm{~g}$ of $\mathrm{N}$ in the form of ammonium nitrate 
Table 1. Source and rate of $\mathrm{N}$ and $\mathrm{Ca}$ application for various treatments. All pots received the same total amount of $\mathrm{N}\left(7.81 \mathrm{~g} /\right.$ plant equivalent to $\left.280 \mathrm{~kg} \cdot \mathrm{ha}^{-1}\right)$. All Ca treated pots received same total amount of $\mathrm{Ca}\left(4.68 \mathrm{~g} /\right.$ plant equivalent to $\left.168 \mathrm{~kg} \cdot \mathrm{ha}^{-1}\right)$ from different source. Nitrogen at 0 and 2 weeks after planting in all treatments and all application times in split $\mathrm{N}$ and non-split $\mathrm{N}$ was from ammonium nitrate.

Amount of $\mathrm{N}$ and $\mathrm{Ca}$ applied (g/plant)

at various time of applications (weeks after planting)

\begin{tabular}{|c|c|c|c|c|c|c|}
\hline \multirow[b]{3}{*}{ Treatment } & \multicolumn{6}{|c|}{ at various time of applications (weeks after planting) } \\
\hline & 0 & 2 & 4 & 6 & 8 & 10 \\
\hline & $\mathrm{N}$ & $\mathrm{N}$ & $\mathrm{N} / \mathrm{Ca}$ & $\mathrm{N} / \mathrm{Ca}$ & $\mathrm{N} / \mathrm{Ca}$ & $\mathrm{N} / \mathrm{Ca}$ \\
\hline Nonsplit N & 1.09 & 3.12 & 3.6/--- & --- & --- & --- \\
\hline Split N & 1.09 & 3.12 & 0.9/--- & 0.9/--- & 0.9/--- & 0.9/--- \\
\hline Split calcium nitrate & 1.09 & 3.12 & $0.9 / 1.17$ & $0.9 / 1.17$ & $0.9 / 1.17$ & $0.9 / 1.17$ \\
\hline Split calcium chloride+ $\mathrm{UAN}^{\mathrm{z}}$ & 1.09 & 3.12 & $0.9 / 1.17$ & $0.9 / 1.17$ & $0.9 / 1.17$ & $0.9 / 1.17$ \\
\hline
\end{tabular}

${ }^{\mathrm{z}} \mathrm{UAN}=$ mixture of $50 \%$ ammonium nitrate and 50\% urea (28:0:0).

was given all the plants which was the equivalent to $112 \mathrm{~kg} \cdot \mathrm{ha}^{-1} \mathrm{~N}$ (Table 1 ). This coincided with the emergence application for field plants. The amount and time of $\mathrm{N}$ applications are presented in Table 1. All treatments received identical amounts $(7.81 \mathrm{~g}$ ) of total $\mathrm{N}$ (equivalent to 280 $\left.\mathrm{kg} \cdot \mathrm{ha}^{-1}\right)$. However, the time of Napplication was different in different treatments as follows.

1) Nonsplit $\mathrm{N}$, all $\mathrm{N}$ at 4 weeks after planting (similar to hilling in a commercial practice) from ammonium nitrate $(34 \mathrm{~N}-0 \mathrm{P}-0 \mathrm{~K})$.

2) Split N, four equal split application from ammonium nitrate.

3) Split calcium nitrate $(9 \mathrm{~N}-0 \mathrm{P}-0 \mathrm{~K}-11 \mathrm{Ca})$.

4) Split UAN $(28 \mathrm{~N}-0 \mathrm{P}-0 \mathrm{~K}, 50 \% \mathrm{~N}$ from urea $+50 \% \mathrm{~N}$ from ammonium nitrate) at 4,6 , 8 , and 10 weeks after planting. These fertilizers were purchased from FS Cooperative, Wis.

All $\mathrm{Ca}$ treatments received the same total amount of $\mathrm{Ca}$ (4.68 g/plant equivalent to $168 \mathrm{~kg} \cdot \mathrm{ha}^{-1}$ ) either from calcium chloride $(0 \mathrm{~N}-0 \mathrm{P}-0 \mathrm{~K}-27.3 \mathrm{Ca})$ or calcium nitrate $(9 \mathrm{~N}-$ $0 \mathrm{P}-0 \mathrm{~K}-11 \mathrm{Ca}$ ) as four equal split applications at $4,6,8$, and 10 weeks after planting. The amount and time of $\mathrm{Ca}$ applications are presented in Table 1. All nutrients were dissolved in water and given to the plants by pouring at the top of soil. Leachate from each pot if any was collected and given back to the same plant.

Tubers were harvested at $125 \mathrm{~d}$ after planting. At harvest, tubers from each pot were rinsed free of soil, weighed individually and graded $(<56 \mathrm{~g}, \geq 56 \mathrm{~g})$. After grading, five tubers $(\geq 56$ g) were collected for the determination of tissue calcium concentration. Samples for tissue calcium analysis were obtained by removing a 1 -cm-thick longitudinal slice from the center of each tuber. The periderm and most of the cortex were removed from the tissue with a razor blade and discarded. The remaining nonperiderm tissue was prepared for $\mathrm{Ca}$ analyses as described by Kratzke and Palta (1986). For this purpose the samples were dried in an oven at $70^{\circ} \mathrm{C}$, ground, weighed and ashed $\left(450^{\circ} \mathrm{C}, 6\right.$ h). The ash was then dissolved in $2 \mathrm{~N} \mathrm{HCl}$. This solution was diluted with a lanthanum chloride $\left(\mathrm{LaCl}_{3} \bullet \mathrm{H}_{2} \mathrm{O}\right)$ solution and distilled-deionized water to obtain samples in a final concentration of $0.2 \mathrm{~N} \mathrm{HCl}$ and $2000 \mathrm{mg} \cdot \mathrm{L}^{-1}$ of lanthanum chloride. Ca concentration was determined by atomic absorption spectrophotometry (Varian model Spectraa-20, Varian Associates, Inc., Sunnyvale, Calif.).

Analyses of variance (ANOVA) were performed to test treatment effects on tuber Ca concentration, total tuber yield, total tuber number, mean tuber weight and the proportion concentration of the tuber nonperiderm tissue as of tubers $>56 \mathrm{~g}$ by using the general linear model procedure of Statistical Analysis System (version 7). Data were analyzed and effects were considered significant if $P \leq 0.05$. After completing the ANOVA, LSD test (alpha $=0.05$ ) was used to compare treatment mean values.

\section{Results}

Application of $\mathrm{Ca}$ either from calcium chloride or calcium nitrate increased the $\mathrm{Ca}$ compared to split and nonsplit $\mathrm{N}$ controls (Fig. 1 and Table 2). Tissue $\mathrm{Ca}$ concentration was highest when calcium chloride was used together with UAN. The nonperiderm Ca concentration increased from $144 \mathrm{ppm}$ in the nonsplit control to $245 \mathrm{ppm}$ in the calcium chloride treatment. Although split $\mathrm{N}$ application tended to increase the average nonperiderm $\mathrm{Ca}$ concentration as compared to nonsplit $\mathrm{N}$, this increase was not significant. There were no significant differences in total tuber yield (mass) per plant among treatments (Fig. 2 and Table 2).

Overall total tuber number per plant was significantly influenced by the application of $\mathrm{Ca}$ (Table 2 and Fig. 3). Plants given $\mathrm{Ca}$ produced fewer tubers than the nonsplit $\mathrm{N}$ and split N controls (Fig. 3). Split application of calcium nitrate produced the lowest number of tubers per plant (Fig. 3). However, there was no significant difference among the two sources of $\mathrm{Ca}$ for the tuber number per plant

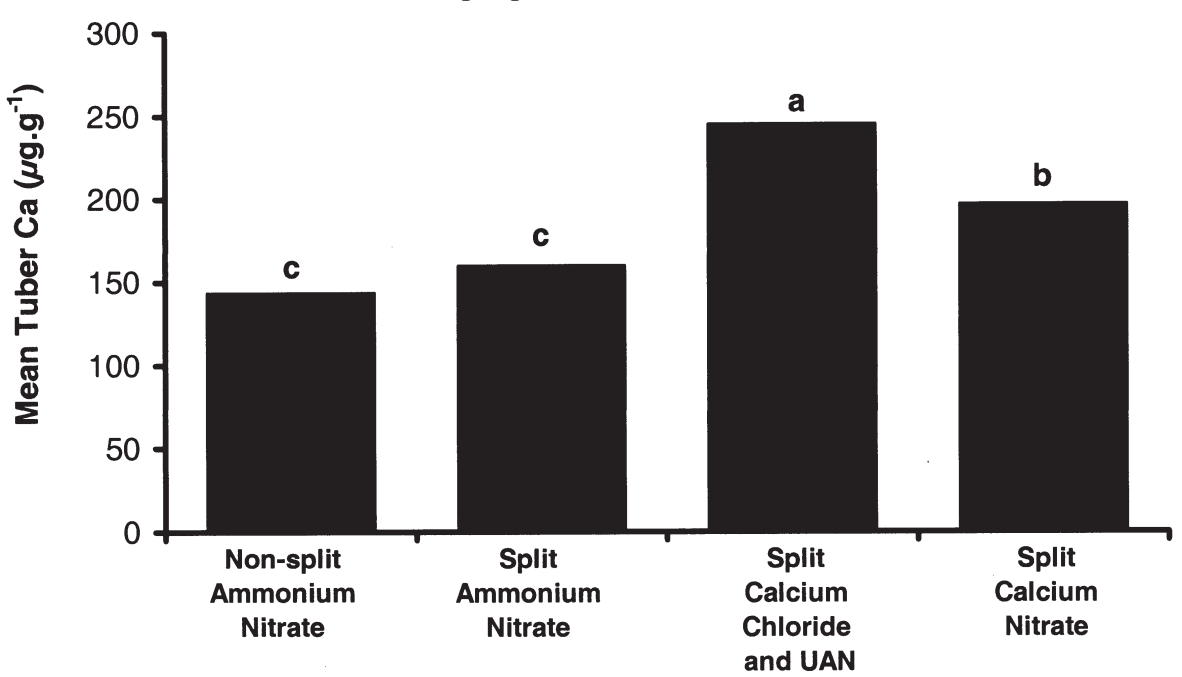

Fig. 1. Treatment effects on nonperiderm tissue Ca concentration of potato tuber. Plots depict the mean tuber $\mathrm{Ca}\left(\mu \mathrm{g} \cdot \mathrm{g}^{-1}\right.$ dry weight) for treatments. Mean values that have the same letter are not significantly different based on the SAS general linear model procedure. LSD (alpha $=0.05$ ). See Table 1 for details of treatments.
(Fig. 3). Average tuber number per plant was 15 in the calcium nitrate treatment as compared to 24 and 21 for the nonsplit and split $\mathrm{N}$ treatments respectively. Mean tuber weight was higher in the $\mathrm{Ca}$ treated plants as compared to the nonsplit $\mathrm{N}$ control but not when compared to split $\mathrm{N}$ control (Fig. 4 and Table 2). There was a significant difference among treatments for the proportions of tuber greater than $56 \mathrm{~g}$ at $p=0.1$. However, this differences was not significant at $p=0.05$ (Table 2). Average tuber weight was highest in the calcium nitrate treatment. In this treatment mean tuber weight was about $60 \mathrm{~g}$ as compared to $42 \mathrm{~g}$ in the nonsplit $\mathrm{N}$ treatment (Fig. 4).

In both the Ca treatments, nearly $50 \%$ of the tubers had tuber weight greater than $56 \mathrm{~g}$ (Fig. $5)$. However, only $29 \%$ of the tubers were $>56$ $\mathrm{g}$ in the nonsplit $\mathrm{N}$ control treatment. The split $\mathrm{N}$ treatment tended to produce larger tubers than the nonsplit $\mathrm{N}$ but these differences were not significant.

A scatter plot of tuber tissue $\mathrm{Ca}$ level and total tuber number for each individual plant is shown in Fig. 6. A quadratic fit showed a significant negative relationship between tuber $\mathrm{Ca}$ and tuber number per plant. As the mean tuber Ca content increased from 100 to 240 ppm the tuber number per plant decreased from about 25 to 15 .

\section{Discussion}

Wisconsin soils routinely show ammonium acetate-extractable Ca levels of 250 to 1000 $\mathrm{mg} \cdot \mathrm{kg}^{-1}$ soil (Simmons and Kelling, 1987; Kleinhenz et al., 1999). The soil used in this study had a Ca level of $350 \mathrm{mg} \cdot \mathrm{kg}^{-1}$, which is considered adequate to satisfy vegetative plant demand for Ca (Simmons and Kelling, 1987; Kleinhenz and Palta, 2002). Consistent with this expectation, our plants grew normally without any $\mathrm{Ca}$ deficiency. Our results showed that in this soil split application of $\mathrm{Ca}$ at the equivalent to $168 \mathrm{~kg} \cdot \mathrm{ha}^{-1}$ from eithercalcium nitrate or calcium chloride increased tuber $\mathrm{Ca}$ concentration in nonperiderm tissue (Fig. 1). These results are 
Table 2. Analyses of variance (ANOVA) for treatment effects.

\begin{tabular}{lcc}
\hline Variable & F value & $P$ \\
\hline Mean tuber calcium & 8.81 & 0.0003 \\
Total tuber yield & 1.19 & 0.3328 \\
Total tuber number & 5.70 & 0.0035 \\
Mean tuber weight & 3.12 & 0.0418 \\
Proportion of tubers $>56 \mathrm{~g}$ & 2.68 & 0.0658 \\
\hline
\end{tabular}

consistent with previous studies (Kleinhenz et al., 1999) and show that application of soluble forms of $\mathrm{Ca}$ during the tuber bulking period can enhance the $\mathrm{Ca}$ level in nonperiderm tissue. Some tubers of the cultivar 'Russet Burbank' have been shown to have tiny roots growing directly out of the tubers during tuber growth and development (Kratzke and Palta, 1985; Struckmeyer and Palta, 1986). These functional roots were shown to be capable of supplying water and inorganic nutrients to the tubers (Kratzke and Palta, 1985). More recently direct evidence for the transport of soil Ca to the tuber via tuber and stolon roots has been presented using ${ }^{45} \mathrm{Ca}$ (Busse and Palta, 2003). Since $\mathrm{Ca}$ moves in the xylem along with water, tuber and stolon roots could carry nutrients such as $\mathrm{Ca}$ to the tubers (Palta, 1996). From these studies it was suggested that by the application of $\mathrm{Ca}$ in the soil surrounding the tuber one should be able enhance tuber $\mathrm{Ca}$ uptake. Later field studies confirmed this suggestion (Gunter et al., 2000; Karlsson et al., 2001; Kleinhenz et al., 1999; Ozgen et al., 2000). The results of our study (Fig. 1) are consistent with these previous studies and support the concept that tuber $\mathrm{Ca}$ concentration can be significantly increased by supplemental $\mathrm{Ca}$ application.

This study provides evidence that supplemental $\mathrm{Ca}$ application can alter tuberization. This research suggests that addition $\mathrm{Ca}$ to soil during the tuberization period can reduce tuber number (Table 2 and Fig. 3). This means that an increased $\mathrm{Ca}$ concentration in the soil may suppress the tuberization signal. The fact that both sources of $\mathrm{Ca}$ (calcium chloride and calcium nitrate) were able to reduce tuber number further suggests that the observed decrease in tuber number is due to $\mathrm{Ca}$ and not the counter anion. The mechanism by which soil Ca may alter tuberization is not known. The tuberization signal is known to be under complex biochemical control involving hormones (Ewing, 1995). There is strong evidence for a critical role of GA in tuberization (Ewing, 1995; Jackson, 1999; Koda and Okazawa, 1983; Xu et al., 1998). There is also evidence that GA in plants can be modulated by a $\mathrm{Ca}$ /calmodulin pathway (Bush et al., 1993; Gilroy and Jones, 1993). Thus, an increase in Ca concentration in the soil may be suppressing tuberization signal by increasing GA. Similarly a decrease in soil Ca may increase tuberization by decreasing GA levels. Further studies are needed to shed light on the mechanism(s) by which soil Ca may modulate tuberization in potato.

Although the main influence of soil Ca was on tuber number our data show that application of Ca during bulking increased tuber weight (Table 2, Figs. 4 and 5). If photosynthetic capacity of the plant remained constant one would expect larger tubers as tuber number

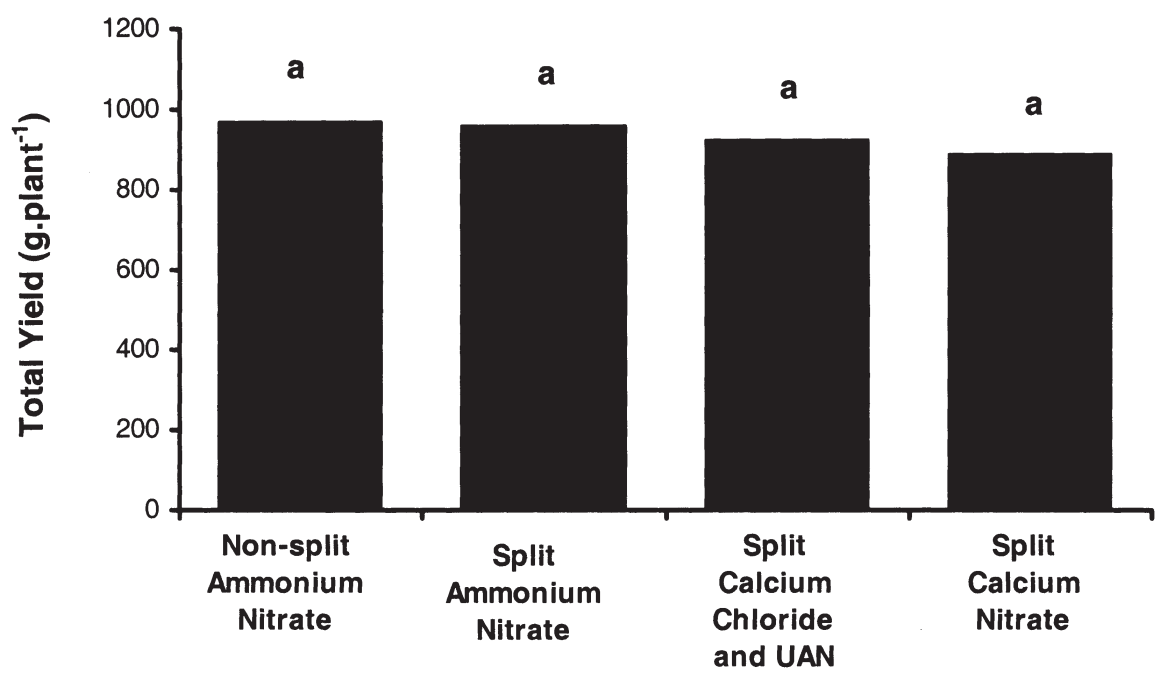

Fig. 2. Treatment effects on total tuber yield. Plots depict the total yield (g/plant) for treatments. Mean values that have same letter are not significantly different based on SAS general linear model procedure. $\operatorname{LSD}($ alpha $=0.05)$.

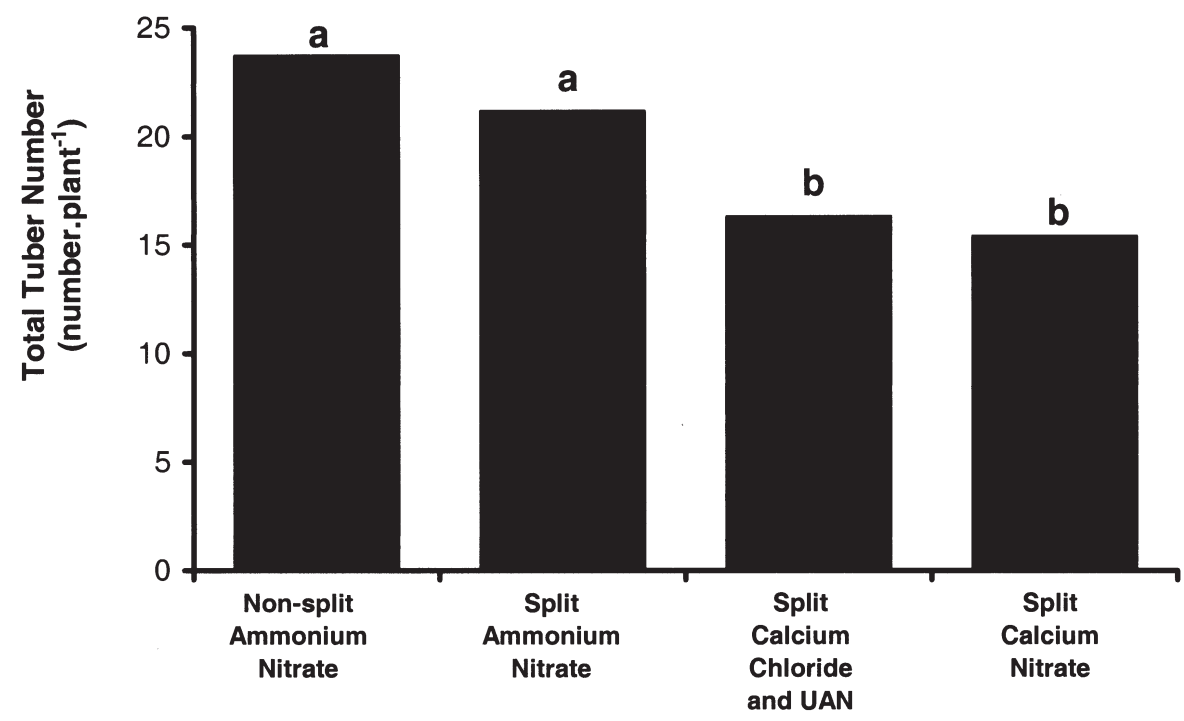

Fig. 3. Treatment effect on total tuber number. Plots depict the total tuber number (number of tubers/plant) for different treatments. Mean values that have same letter are not significantly different based on SAS general linear model procedure. LSD $($ alpha $=0.05)$.

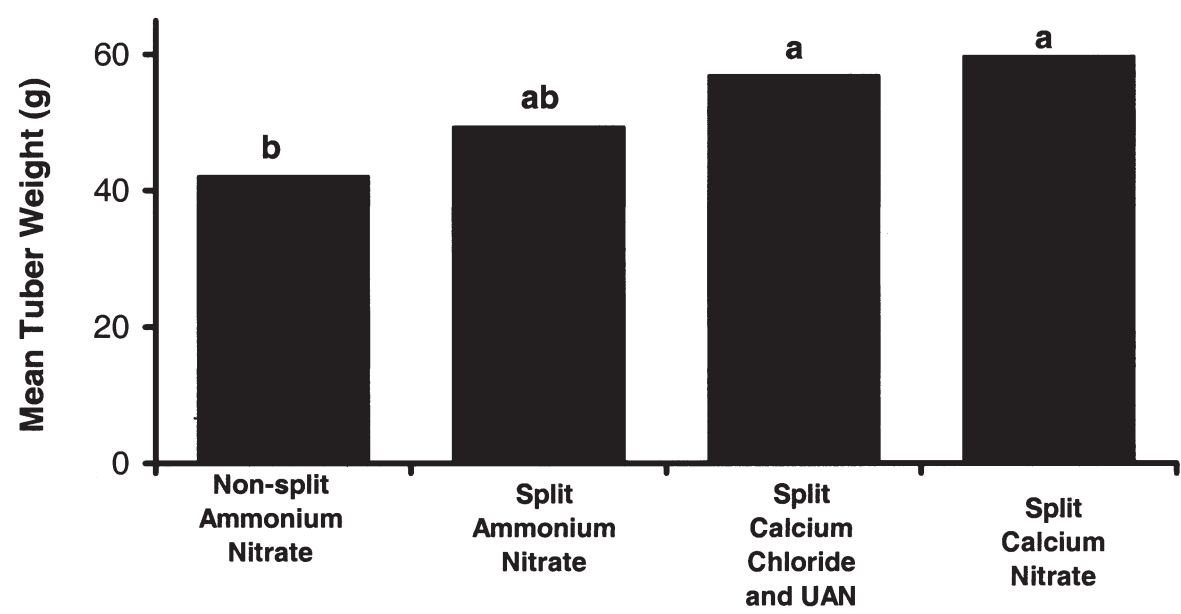

Fig. 4. Treatment effect on tuber weight. Plots depict the mean tuber weight (g) for different treatments Mean values that have same letter are not significantly different based on SAS general linear model procedure. LSD $($ alpha $=0.05)$. 


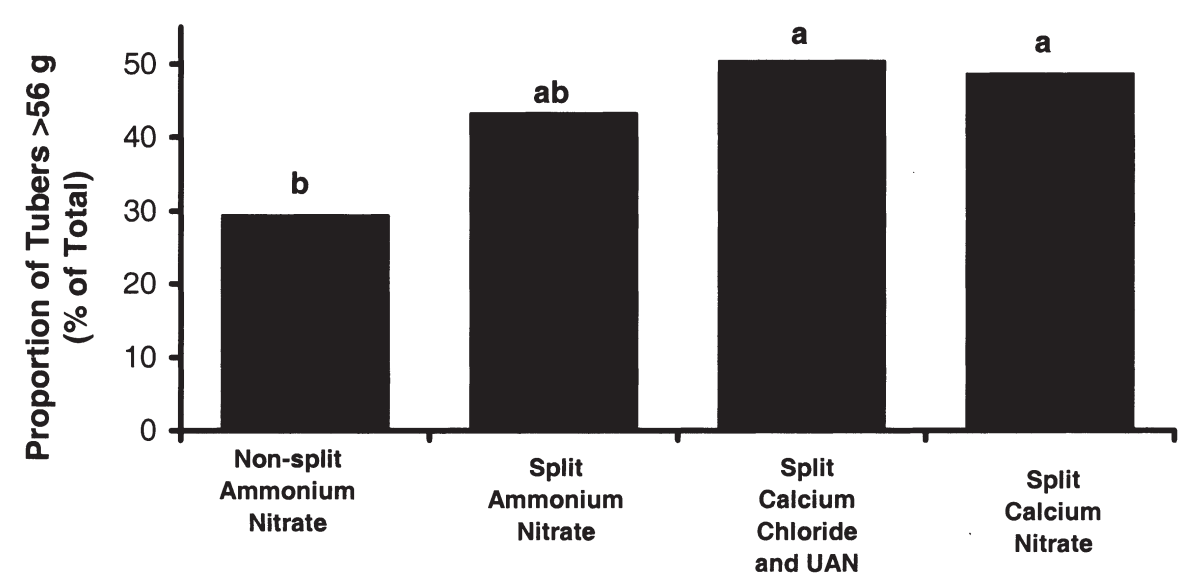

Fig. 5. Treatment effect on tuber grade. Plots depict the proportion of tuber $>56 \mathrm{~g}(\%$ of total) treatments. Mean values that have same letter are not significantly different based on SAS general linear model procedure. LSD $($ alpha $=0.05)$.

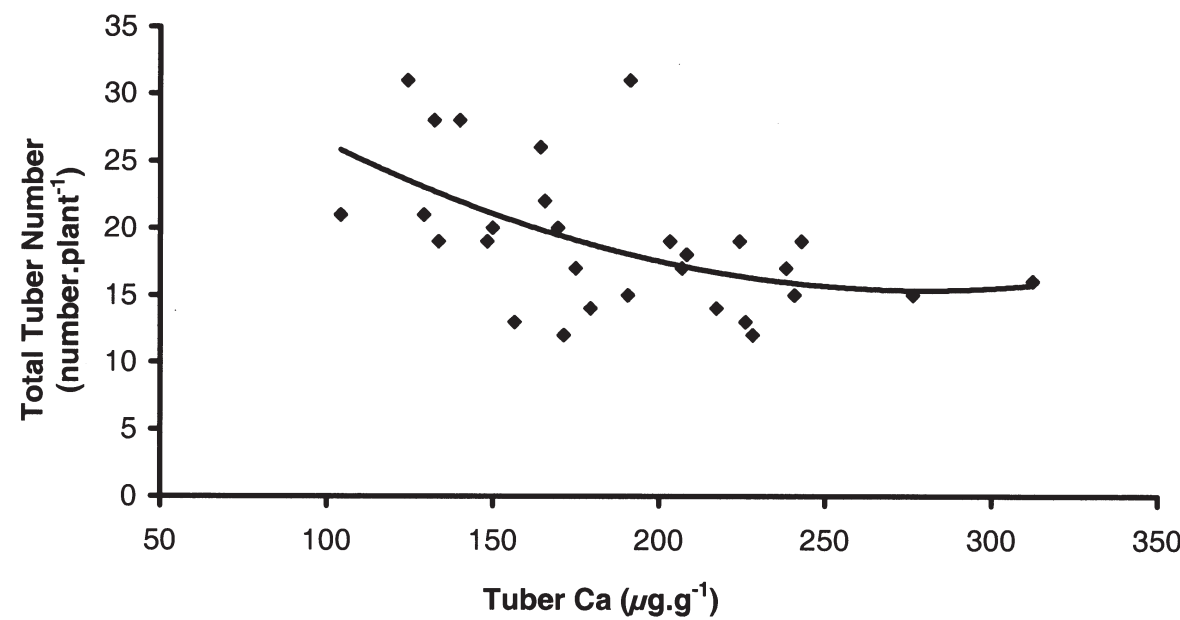

Fig. 6. Scatter plot of the relationship between non-periderm tissue Ca and total tuber number per plant. Each point indicates the tuber Ca concentration and tuber number of an individual plant. Quadratic equation (Pearson correlation) provided best fit for these data set. Model for the graph is $\mathrm{y}=0.0003 \mathrm{x}^{2}$ $-0.1897 \mathrm{x}+41.906 . R^{2}=0.2782$. Significant at $P<0.05$.

per plant decreased. The fact that total tuber yield was not affected by soil Ca application further supports that explanation. These results are also consistent with those reported by Simmons and Kelling (1987). They reported an improvement in tuber grade by supplemental $\mathrm{Ca}$ application under field conditions in a sandy soil. They however did not report any data on tuber number. Larger tuber size especially in the Russet varieties is commercially desired. However, seed growers desire larger number of small size tubers. Results of our study may have important implications for commercial production of potatoes. By manipulating soil $\mathrm{Ca}$ levels growers may be able to manipulate tuber number and size.

\section{Literature Cited}

Balamani, V., K. Veluthambi, and B.W. Poovaiah. 1986. Effect of calcium on tuberization in potato. Plant Physiol. 80:856-858.

Batutis, E.J. and E.E. Ewing. 1982. Far-red reversal of red light effect during long-night induction of potato (Solanum tuberosum L.) tuberization. Plant Physiol. 69:672-674.

Bush, D.S., A.K. Biswas, and R.L. Jones. 1993. Hormonal regulation of $\mathrm{Ca}^{2+}$ transport in the endomembrane system of the barley aleurone. Planta 189:507-515.

Busse, J.S. and J.P. Palta. 2003. Uptake and transport of calcium to potato tubers using ${ }^{45} \mathrm{Ca} .87^{\text {th }}$ Annu.Mtg. Potato Assn. Amer. Abst. P3.

Clarkson, D.T. and J.B. Hanson. 1980. The mineral nutrition of higher plants. Annu. Rev. Plant Physiol. 31:239-298.

Ewing, E.E. 1995. The role of hormones in potato (Solanum Tuberosum L.) tuberization, p. 698-721. In: P.J. Davies (ed.). Plant hormones. 2nd ed. Kluwer Academic Publishers, Netherlands.

Ewing, E.E. and P.C. Struik. 1992. Tuber formation in potato: Induction, initiation, and growth. Hort. Rev. 14:89-108.

Ewing, E.E. and P.F. Wareing. 1978. Shoot, stolon, and tuber formation on potato (Solanum tuberosum L.) Plant Physiol. 61:348-353.

Gilroy, S. and R.L. Jones. 1993. Calmodulin stimulation of unidirectional calcium uptake by endoplasmic reticulum of barley aleurone. Planta 190:289-296.

Gunter, C., S. Ozgen, B. Karlsson, and J.P. Palta. 2000. Calcium application at preemergence and during bulking may improve tuber quality and grade. HortScience 35:498.

Hepler, P.K. and R.O. Wayne. 1985. Calcium and plant development. Annu. Rev. Plant Physiol. 36:397-439.

Jackson, S.D. 1999. Multiple signaling pathways control tuber induction in potato. Plant Physiol. 119:1-8.

Jackson, S.D. and S. Prat. 1996. Control of tuberization in potato gibberellins and phytocrome B. Physiol. Plant 98:407-412.

Karlsson, B., J.P. Palta and S. Ozgen. 2001. Reduction of potato tuber bruising and internal defects by supplemental calcium field application. Amer. J. Potato Res. 78:462.

Kleinhenz, M.D. and J.P. Palta. 2002. Root zone calcium modulates the response of potato plants to heat stress. Physiol. Plant. 115:111-118.

Kleinhenz, M.D., J.P. Palta, C.C. Gunter, and K.A. Kelling. 1999. Impact of source and timing of calcium and nitrogen on 'Atlantic' potato tuber calcium concentrations and internal quality. J. Amer. Soc. Hort. Sci. 124:498-506.

Koda,Y. and Y. Okazawa. 1983. Influence of environmental, hormonal and nutritional factors on potato tuberization in vitro. Jpn. J. Crop Sci. 52(4):582-591.

Kratzke, M.G. and J.P. Palta 1986. Calcium accumulation in potato tubers: Role of basal roots. HortScience 21:1022-1024.

Kratzke, M.G. and J.P. Palta. 1985. Evidence for existence of functional roots on potato tubers and stolons: Significance in water transport to the tuber. Amer. Potato J. 62: 227-236

Krauss, A. 1985. Interaction of nitrogen nutrition, phytohormones and tuberization, p. 209-231. In: PH Li (ed.). Potato physiology. Academic Press, London.

Krauss, A. and H. Marschner. 1982. Influence of nitrogen nutrition, daylength, and temperature on contents of gibberellic and abscisic acid and on tuberization in potato plants. Potato Res. 25:13-21.

Li, P.H. 1985. Potato physiology. Academic Press, London. p. 209-260.

Marme, D. 1982. The role of calcium and calmodulin in plants. What's New Plant Physiol. 13:37-40.

Marschner, H. 1995. Mineral nutrition of higher plants. $2^{\text {nd }}$ ed. Academic Press, London p. 285-299.

Menzel, C.M. 1980. Tuberization in potato at high temperatures: Responses to gibberellin and growth inhibitors. Ann. Bot. 46:259-265.

Menzel, C.M. 1983. Tuberization in potato at high temperatures: Gibberellin content and transport from buds. Ann. Bot. 52:697-702.

Menzel, C.M. 1985. Tuberization in potato at high temperatures: Responses to exogenous gibberellin, cytokinin and ethylene. Potato Res. 28:263-266.

Murashige, T. F. Skoog. 1962. A revised medium for rapid growth and bioassay with tobacco tissue cultures. Physiol. Plant. 15:473-497.

Ozgen, S., C. Gunter, B. Karlsson and J.P. Palta. 2000. Supplemental application of calcium and nitrogen improves internal quality of 'Russet Burbank' potatoes. HortScience 35:498.

Palta, J.P. 1996. Role of calcium in plant responses to stresses: Linking basic research to the solution of practical problems. Proceedings of Colloquium: Recent advances in plant responses to stress: Bridging the gap between science and technology. HortScience 31(1):51-57.

Poovaiah, B.W. 1985. Role of calcium and calmodulin in plant growth and development. HortScience 20:347-352.

Poovaiah, B.W. and A.S.N. Reddy. 1987. Calcium messenger system in plants. CRC Crit. Rev. Plant Sci. 6:47-102.

Poovaiah, B.W., D. Takezawa, G. An, and T-J. Han. 1996. Regulated expression of a calmodulin isoform alters growth and development in potato. J. Plant Physiol. 149:553-558.

Roberts, D.M. and A.C. Harmon. 1992. Calcium-modulated proteins: targets of intracellular calcium signals in higher plants. Annu. Rev. Plant Physiol. Plant Mol. Biol. 43:375-414.

Simmons, K.E. and K.A. Kelling. 1987. Potato responses to calcium application on several soil types. Amer. Potato J. 64:119-136.

Snyder, R.G. and E.E. Ewing. 1989. Interactive effects of temperature, photoperiod and cultivar on tuberization of potato cuttings. HortScience 24:336-338.

Steffen, K.L. and J.P. Palta. 1986. Effect of light on photosynthetic capacity during cold acclimation in a cold-sensitive and cold-tolerant potato species. Physiol. Plant. 66:353-359.

Struckmeyer, B.E. and J.P. Palta 1986. Anatomical evidence for the existence of roots on potato tubers and stolons. Amer. Potato J. 63:57-60.

Xu, X, A.A. van Lammeren, E. Vermeer, and D. Vreugdenhil. 1998. The role of gibberellin, abscisic acid, and sucrose in the regulation of potato tuber formation in vitro. Plant Physiol. 117:575-584. 